\section{A 21} 原発性肺癌に対するlimited operationの成績 長崎大学第一外科

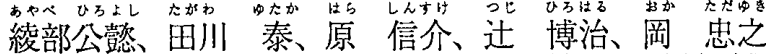

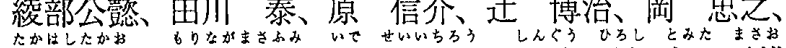
高橋孝郎、森永真史、井手誠一郎、新宮 浩、富田正雄

原発性肺癌に対す方縮小手術(肺部分または区域切除 術)の根治手術としての有用性について報告する。

平成6年12月までに当科で行った原発性肺癌に対す る縮小手術は91例である。70才以上が47例(51.6\%)を占 めた。91例中3例は同時性多発癌のため94回の縮小手術 が行われた。縮小手術の術式は区域切除 84、部分切除 10であった。なお、7例の肺門部早期扁平上皮癌に対し ては気管支形成術併用肺区域切除を行った。91例中10 例は遠隔転移、胸膜播種、癌遺残のため絶対的非治瘾切 除となった。組織型は腺癌 55、扁平上皮癌 32、大細胞 癌 1、小細胞癌 4、その他 2であり、進行度はstage 0、 2、I 64(70.3\%)、II 4、IIIA 12、III B 4 IV 5であった。 術後合併症を28例(30.8\%)にみたが、持続性肺胞㾇、 痰喀出障害、無気肺が主なものであった。しかし術後 30日以内の手術死亡は0であり、大動脈瘤切除と同時手 術の行われた1例 $(1 \%)$ が入院死ししたにすぎない。

予後については治療切除例全体の 5 生率は64.2\%で あったが、stage Iに限ると73.9\%と肺葉切除例の5生率 に劣らない結果であった。特に腫汮径 $2 \mathrm{~cm}$ 以下、高令者、 高分化例、Diploid肺癌では予後良好の傾向にあった。

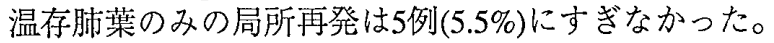
絶対的非治瘺切除例の予後は不良でreduction surgery の意義は認められなかった。

\section{A 23} 原発性肺癌に対する積極的縮小手術： Extended segmentectomyの肺機能に及ぼす影響

兵庫県立成人病センター胸部外科

宮本良文、坪畐紀明、吉村雅裕、室谷陽裕、針生智樹

【目的】1992年 1 月よりX線上 $2 \mathrm{~cm}$ 以下の小型肺癌に 対する積極的縮小手術として Extended segmentectomy (区域切除十リンパ節清郭清) を行ってきた。その術 前後の肺機能につき検討したので報告する。

【対象と方法】1992年 1 月より1994年 2 月までに本セ ンターにおいてExtended segmentectomyが施行された 15例中、術後に肺機能が測定された11例を対象とした。 切除区域数は 1 区域 $\leqq 2$ 例 $<2$ 区域、2 区域 55 例 $<$ 3 区域、3区域 44 例であり、術前と術後 6 月前後の 肺活量、1 秒量、拉よびその変化率 $\triangle \mathrm{VC} 、 \triangle \mathrm{FEV} 1.0$ を検討した。

【結果】術前後の肺活量の平均値はそれぞれ3019 $\mathrm{ml} 、 2633 \pm 868 \mathrm{ml}$ 、術前後の1 秒量の平均值はそれぞ

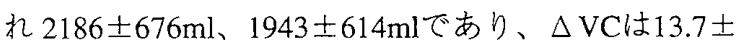

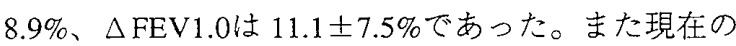
ところ当センターにおけるExtended segmentectomy施 行例には術後合併症や再発を認めていない。

【結論】我々の行っている積極的縮小手術 - Extended segmentectomy - は肺機能の温存に有用な術式である ことが確認された。 $\triangle 12$ Active limited operation $の$ 諸問題

大阪府立成人病センター第二外科

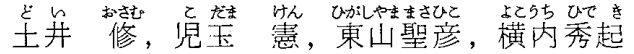

【目的】48例の小型肺癌飞 Radical segmentectomy t 施行し、その経験から本法の諸問題につを検討した。

【結果】開胸術式：広背筋温存前方皮膚切開は美容上 や手術時間の短縮、上肢つ挙上障害飞有利であった。 区域切除：YAG-Laser切離は staplerによる肺容積の 損失、断端が不均等となり易い欠点を克服し得た。1 例の断端再発をみたが stapler 使用例であった。

縱隔リンパ節郭清：R0,1の2例（4\%)飞縦隔りンパ 節再発学庆。 $\mathrm{T} 1,2 \mathrm{n} 1$ (一) 174 例の扁平上皮癌、腺 癌で C T上リンパ節腫大の無い縦隔 micro- skipmetastases の頻度は4\%であったが、縮小手術に和ける縦 隔完全郭清の是非について結論をくだし難い。 同一肺葉内 $\mathrm{pm}$ ：榆討した同一肺 $\mathrm{pm}$ はすべて原発巣 と同一区域内で、しか子T1N0にはみられていない。 現在迄残存肺からの再発惊無く、絔小手術での pm 遺 残の危険将少ない。今後 spiral CTが有用であろう。 air leak：1例飞遅発性肺瘦の市为再開胸を要した。 動物実験で有効であった Gelatin-resortinol formaldehyde - glutaldehyde 糊の臨床応用を袷討中である。 遠隔成績： 3 生率 $83 \% 、 5$ 生率 $76 \%$ で標準切除と比 較して遜色がなかった。

結論：小型肺癌への縮小手術は標準術式に代り得る。

\section{$A 24^{\mathrm{pm} \text { 陽性肺癌切除例の検討 }}$}

岡虹大学第2 2 外科

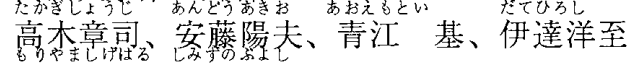
森山重治、清水信義

【目的】当科に扔ける $\mathrm{p} \mathrm{m}$ 陽性肺癌切除例の治療成績 を検討した。【対象】1976年から93年までの18年間 の肺癌切除例1048例のうち p m陽性例は 58 例 $(5.5 \%)$ で、そのうち手術関連死及び小細胞癌を除く56 例 （pm1 48例、pm2 8例）を対象とした。年齢は35才 加81才 (平均 62.2 才) 、男性 43 例、女性 13 例。組 織型は腺癌 37 例、扁平上皮癌 17 例、腺扁平上皮癌 1 例、 大細胞癌1例であった。【結果】1） p m 陽性例の 5 生率は $31.7 \%$ で四 B 期切除例 $15.1 \%$ と有意差はなか ったがN $N$ 期切除例の 3 生率 $0 \%$ 上り有意に良好であっ た。2）p T、pN因子別の 5生率はそれぞれp T 1（15 例） $84.6 \% 、 \mathrm{pT} 2$ (30例) $12.9 \%$ また $\mathrm{pN} 0$ (28例) $51.3 \% 、 \mathrm{pN} 1$ (7例) $28.6 \% 、 \mathrm{pN} 2$ (16例) $6.7 \%$ と T1がp T2に比べまた $\mathrm{pN} 0 、 \mathrm{pN} 1$ が $\mathrm{p} N 2$ に比べそれ ぞれ有意に良好であった。3）術前評価PMO とPM1の 5 生率はそれぞれ $27.1 \% 、 42.9 \%$ と有意差は認めなか った。4) p m2 症例のうち $\mathrm{pN} 2$ (4例) は全例9ヶ月 以内に死亡したが、 $\mathrm{p} \mathrm{m} 2 て ゙ \mathrm{pN} 0$ （4例）は2年以上生 存中である。【結語】p T 1及び p N 0 の予後は比較的 良好であった。術前評価PM1の5生率は比較的良好で PMO と有意差は認めなかった。 